\title{
Adolescents Who Intend to Change Multiple Health Behaviours Choose Greater Exposure to an Internet- delivered Intervention
}

Citation for published version (APA):

Crutzen, R. M. M., de Nooijer, J., Candel, M. J. J. M., \& de Vries, N. K. (2008). Adolescents Who Intend to Change Multiple Health Behaviours Choose Greater Exposure to an Internet-delivered Intervention. Journal of Health Psychology, 13(7), 906-11. https://doi.org/10.1177/1359105308095064

Document status and date:

Published: 01/01/2008

DOI:

10.1177/1359105308095064

Document Version:

Publisher's PDF, also known as Version of record

\section{Document license:}

Taverne

Please check the document version of this publication:

- A submitted manuscript is the version of the article upon submission and before peer-review. There can be important differences between the submitted version and the official published version of record.

People interested in the research are advised to contact the author for the final version of the publication, or visit the DOI to the publisher's website.

- The final author version and the galley proof are versions of the publication after peer review.

- The final published version features the final layout of the paper including the volume, issue and page numbers.

Link to publication

\footnotetext{
General rights rights.

- You may freely distribute the URL identifying the publication in the public portal. please follow below link for the End User Agreement:

www.umlib.nl/taverne-license

Take down policy

If you believe that this document breaches copyright please contact us at:

repository@maastrichtuniversity.nl

providing details and we will investigate your claim.
}

Copyright and moral rights for the publications made accessible in the public portal are retained by the authors and/or other copyright owners and it is a condition of accessing publications that users recognise and abide by the legal requirements associated with these

- Users may download and print one copy of any publication from the public portal for the purpose of private study or research.

- You may not further distribute the material or use it for any profit-making activity or commercial gain

If the publication is distributed under the terms of Article $25 \mathrm{fa}$ of the Dutch Copyright Act, indicated by the "Taverne" license above, 


\section{Adolescents Who Intend to Change Multiple Health Behaviours Choose Greater Exposure to an Internet-delivered Intervention}

RIK CRUTZEN, JASCHA DE NOOIJER, MATH J. J. M. CANDEL, \& NANNE K. DE VRIES Maastricht University, The Netherlands

ACKNOWLEDGEMENTS. This study was supported by a grant from the OGZ Fund.

COMPETING INTERESTS: None declared.

ADDRESS. Correspondence should be directed to:

RIK CRUTZEN, Department of Health Education and Health Promotion, Maastricht University, PO Box 616, 6200 MD Maastricht, The Netherlands. [email: Rik.Crutzen@GVO.unimaas.nl]

\section{JHP}

Journal of Health Psychology Copyright (C) 2008 SAGE Publications Los Angeles, London, New Delhi and Singapore www.sagepublications.com Vol 13(7) 906-911

DOI: $10.1177 / 1359105308095064$

\section{Keywords}

- adolescents

- exposure

- intention

- Internet

- intervention 


\section{Introduction}

DESPITE an explosive growth of Internet applications in health education practice (Bernhardt \& Hubley, 2001) it appears that exposure rates to Internet-delivered behaviour change interventions are low (Evers, Cummins, Prochaska, \& Prochaska, 2005). Nevertheless, there is little scientific knowledge about how to improve these rates. Exposure can be distinguished in three different aspects: (1) a first visit; (2) staying on the intervention long enough to use and process the information; and (3) revisiting to the intervention (the latter is optional). In this article, we studied the intention to change behaviour in relation to exposure to an Internet-delivered lifestyle intervention. In the context of this intervention, we focused on the second aspect of exposure: stay on the intervention and make use of its functionalities. We especially took intention to change behaviour into account, since this is the best predictor of behaviour itself (Godin \& Kok, 1996).

Since many health risk behaviours are acquired during adolescence and track into adulthood (Kelder, Perry, Klepp, \& Lytle, 1994), Dutch Community Health Services (CHSs) have a legal obligation to monitor adolescents' health in order to set priorities for health promotion activities (Meijer, 1991). The E-MOVO (Dutch acronym that stands for Electronic Monitoring and Health Promotion) project provides insight into adolescents' health and is a large-scale collaboration between seven CHSs (in the eastern part of the Netherlands) and Maastricht University to develop and implement an electronic monitoring instrument with the opportunity to provide tailored feedback at the individual level (De Nooijer \& De Vries, 2006).

Within the E-MOVO project, monitoring is done via the Internet. The combination of an Internetdelivered monitoring instrument with the opportunity to provide tailored feedback at the individual level makes E-MOVO unique. In this way, one can reach adolescents who otherwise would not seek healthy lifestyle information and tailor this information. Within E-MOVO this is done via a socalled E-MOVO score which adolescents get after they have completed the monitoring questionnaire. This score is tailored on lifestyle behaviours and consists of feedback on current behaviour and a colour code to visualize whether their reported behaviour was in line (green), roughly in line (orange) or not in line (red) with the Dutch health recommendations (e.g. eat at least two pieces of fruit a day). With this E-MOVO score, two links to subject specific sites per lifestyle behaviour were offered to obtain more information. With regard to fruit consumption and smoking there was an additional link to obtain tailored advice.

The main research question of this study focused on the relationship between adolescents' intention to change their behaviour and their use of E-MOVO's functionalities. The use of E-MOVO's functionalities was divided into reading the E-MOVO score, clicking on links to obtain more information and clicking on links to obtain tailored advice. We also took several demographic variables into account (age, sex, level of education) as they do influence the use of e-health functionalities in general (Gray, Klein, Noyce, Sesselberg, \& Cantrill, 2005; Rice, 2006).

\section{Methods}

\section{Procedures and participants}

All high schools in the region of the collaborating CHSs were approached to participate in this project. Since the CHSs have had previous contact with schools through their regular monitoring activities, response rates were high, varying from 73-93 per cent ( $44 \%$ in one region due to a merge of CHSs). During one class period (approximately 45 minutes) participants filled in the monitoring questionnaire, in the course of compulsory school activities and on separate computers. Due to the legal obligation of Dutch CHSs to monitor the health of adolescents, no parental consent was needed. However, the project is registered at the Dutch Data Protection Authority, which supervises the fair and lawful use and security of personal data. Participants had to log on afterwards to obtain their individually tailored feedback due to the fact that participants were only available for one class period.

Two months after participants filled in the monitoring questionnaire, they were invited by e-mail to fill in a second questionnaire on a voluntary basis during their spare time. The main purpose of this questionnaire was to evaluate the E-MOVO project (De Nooijer, Veling, Ton, De Vries, \& De Vries, 2008), but also to assess whether or not participants had read their E-MOVO score.

\section{Measures}

Adolescents were asked to report their age, sex and level of education. Adolescents were divided into 
younger (second year students, approximately 14-15 years old) and older students (fourth year students, approximately 16-17 years old). Educational level was categorized into a low (preparatory secondary vocational education) and a high (senior general secondary education or university preparatory education) level.

Questionnaire items were constructed on the basis of several existing (some validated) instruments, which were previously used by CHSs (De Nooijer \& De Vries, 2006). Intention to change behaviour was measured using five-point Likert scales ranging from certainly not $(-2)$ to certainly yes $(+2)$ (e.g. 'Do you intent to eat more fruit in the near future?'). We measured physical activity in minutes, fruit consumption in portions, whether or not participants smoke, drink alcohol (consumption in standard glasses) and use condoms (five-point Likert scale, ranging from never to always).

Furthermore, it was registered whether or not participants logged on to the website. Per lifestyle behaviour it had been registered on how many links participants clicked to obtain more information or tailored advice (if applicable). In the second questionnaire, participants reported for each lifestyle behaviour whether or not they read their E-MOVO score.

\section{Analyses}

Since data were nested (students within classes within schools), we used multilevel analyses to study the relationship between (intention to change) behaviour and adolescents' use of E-MOVO's functionalities. Variables included were demographic variables, behaviour measures and intention to change behaviour. We used top-down testing, with a level of significance of .05 , resulting in a model per lifestyle behaviour with only significant variables left.

\section{Results}

In total, 35,104 participants completed the initial questionnaire. Participants who attended classes covering different educational levels were excluded from further analyses. In total, 33,644 participants $(95.8 \%)$ from 144 schools were included in analyses. Of these participants, 50.8 per cent were girls and 44.6 per cent attended higher educational level. Relatively more girls attended higher educational level $\left(\chi^{2}=12.338, p<.001\right)$. More than half of the participants $(55.7 \%)$ logged on to the website.
Older adolescents were more inclined to $\log$ on $(\beta=0.242, p<.0001)$, as were girls $(\beta=-0.372$, $p<.0001)$ and adolescents who attended a higher educational level $(\beta=0.273, p<.0001)$. Of those participants who provided their e-mail address $(N=$ $25,195), 650$ completed the second questionnaire (a response of $2.6 \%$ ). Compared to those who did not complete the second questionnaire, these participants included more girls $\left(\chi^{2}=63.730, p<.001\right)$ and were more likely to attend a higher educational level $\left(\chi^{2}=84.032, p<.001\right)$. They were less physically active $(t=6.932, p<.001)$ and more likely to be a non-smoker $\left(\chi^{2}=30.641, p<.001\right)$. They also drank less $(t=5.483, p<.001)$. With regard to their intention to change behaviour, they only had a higher intention to use condoms $(t=5.409, p<.001)$.

\section{Second questionnaire}

Adolescents with a high intention to be more physically active were more inclined to read their E-MOVO score on physical activity (Table 1). Adolescents who attended a lower educational level were more inclined to read their score on fruit consumption. With regard to smoking, non-smoking boys were more inclined to read their score on smoking. Adolescents who did smoke, but also had a low intention to stop smoking, were also more inclined to read their score on smoking. Adolescents with high alcohol consumption were more inclined to read their score on alcohol consumption. With regard to condom use, there were no significant results.

\section{Observational data}

After reading their E-MOVO score, 1535 adolescents $(4.6 \%)$ clicked on at least one link to obtain more information or tailored advice. Girls were more inclined to click on links to obtain more information about physical activity and fruit consumption. Adolescents who did not smoke, but had a high intention to start smoking, were more inclined to click on links to obtain more information about smoking. Also, adolescents with high alcohol consumption and a high intention to drink more alcohol were more likely to click on a link to obtain more information. No significant results were found with regard to condom use. Girls, adolescents who attended a higher educational level and those with a high intention to eat more fruit, were more inclined to click on a link to obtain tailored advice on fruit consumption. For both (smokers and non-smokers), girls and adolescents who attended a higher educational level were more inclined to click on a link to 
obtain tailored advice on smoking. We found the same results for non-smokers with a high intention to start smoking and smokers with a low intention to stop smoking.

\section{Discussion}

Adolescents with a high intention to start smoking and to drink more alcohol were more inclined to use E-MOVO's functionalities. Information and tailored advice that adolescents get should focus on changing this intention into an intention to change behaviour in a healthy way. With regard to physical activity and fruit consumption we found that those who had a higher intention to be more physically active and to eat more fruit, were more inclined to use E-MOVO's functionalities. Since these adolescents already have a high intention to change behaviour in a healthy way, information and tailored advice they get should focus on reinforcing the transition from intention to behaviour. Other research has shown that risk taking behaviours (start smoking, drink more alcohol) (De Vries et al., 2008) and energy balance-related behaviours (more physical activity, higher fruit consumption) (Kremers, De Bruijn, Schaalma, \& Brug, 2004) are clustered. These findings can be extended to exposure to Internet-delivered interventions aimed at changing these behaviours. However, we did not find these results with regard to smoking cessation and condom use. Those can be seen as risk avoidance behaviours, just like energy balance-related behaviours. In contrast to energy balance-related behaviours, there is an absolute norm with regard to smoking (no smoking, not even one puff) and using condoms (every time when sexual intercourse takes place) and therefore the consequences of conducting these behaviours according to the Dutch health recommendations are more resolute.

Although we have obtained more insight, this is only based on one intervention which, nevertheless, focuses on multiple health risk behaviours. Intention to change behaviour was not significant in all multilevel models, but, if present, we found a consistent pattern of effects. However, this pattern can also be caused by the fact that people can achieve a goal (e.g. being healthy) by means of a variety of behaviours which are more or less salient to each individual (Scheier \& Carver, 2003). Therefore, experimental studies are needed to investigate this possible explanation in more detail. 
The percentage of participants that logged on to the website was high, especially taking into account that adolescents frequently fail to realize their need for health education (Paperny, Aono, Lehman, Hammar, \& Risser, 1990). However, there was still a big gap between the percentage of participants that logged on to the website and the percentage of participants that clicked on at least one link to obtain more information or tailored advice. Reasons indicated by adolescents (De Nooijer et al., 2008) were that they simply did not want to obtain more information and because they did not notice the links since their lay-out was not in line with the default hyperlink lay-out (blue, underlined). Another explanation is that users do not prefer Internet-delivered interventions that continually send users 'off-site' (Kerr, Murray, Stevenson, Gore, \& Nazareth, 2006).

Due to technical flaws, the results of whether or not participants read their E-MOVO score per theme were only based on self-report. To get more insight into exposure to Internet-delivered interventions, a crucial step in data-gathering is to register as many user activities as possible. Also the fact that participants had to fill in the second questionnaire two months after they filled in the monitoring questionnaire may have biased the results. Furthermore, there was a low response rate for the second questionnaire. Besides time delay, this could also be due to the fact that participants had to fill in the second questionnaire in their spare time and it was not part of obligatory school activities. No second prompt was used, to prevent an even longer time delay between use of E-MOVO and the second questionnaire.

\section{Conclusion}

There is a clustering of risk taking and energy balance-related behaviours with regard to the relationship between intention to change multiple behaviours and adolescents' exposure to E-MOVO's functionalities, which should be taken into account with the design of Internet-delivered interventions.

\section{References}

Bernhardt, J. M., \& Hubley, J. (2001). Health education and the Internet: The beginning of a revolution. Health Education Research, 16, 643-645.

De Nooijer, J., \& De Vries, N. K. (2006). Monitoring health risk behavior of Dutch adolescents and the development of health promoting policies and activities: The E-MOVO project. Health Promotion International, 22, 5-10.

De Nooijer, J., Veling, M. L., Ton, A., De Vries, H., \& De Vries, N. K. (2008). Electronic monitoring and health promotion: The evaluation of the E-MOVO website by adolescents. Health Education Research, 23, 382-391.

De Vries, H., Van 't Riet, J., Spigt, M., Metsemakers, J., van den Akker, M., Vermunt, J. K., \& Kremers, S. P. J. (2008). Clusters of lifestyle behaviors: Results from the Dutch SMILE study. Preventive Medicine, 46, 203-208.

Evers, K. E., Cummins, C. O., Prochaska, J. O., \& Prochaska, J. M. (2005). Online health behavior and disease management programs: Are we ready for them? Are they ready for us? Journal of Medical Internet Research, 7, e27.

Godin, G., \& Kok, G. (1996). The theory of planned behavior: A review of its applications to health-related behaviors. American Journal of Health Promotion, 11, 87-98.

Gray, N. J., Klein, J. D., Noyce, P. R., Sesselberg, T. S., \& Cantrill, J. A. (2005). Health information-seeking behaviour in adolescence: The place of the Internet. Social Science \& Medicine, 60, 1467-1478.

Kelder, S. H., Perry, C. L., Klepp, K. I., \& Lytle, L. L. (1994). Longitudinal tracking of adolescent smoking, physical activity, and food choice behaviors. American Journal of Public Health, 84, 1121-1126.

Kerr, C., Murray, E., Stevenson, F., Gore, C., \& Nazareth, I. (2006). Internet interventions for long-term conditions: Patient and caregiver quality criteria. Journal of Medical Internet Research, 8, e13.

Kremers, S. P. J., De Bruijn, G. J., Schaalma, H., \& Brug, J. (2004). Clustering of energy balance-related behaviours and their intrapersonal determinants. Psychology and Health, 19, 595-606.

Meijer, A. W. M. (1991). Plaats en functies van de Nederlandse G.G.D.-en [Location and functions of Dutch Community Health Services]. In E. De Leeuw (Ed.), Gezonde steden [Healthy cities] (pp. 109-131). Assen/Maastricht: Van Gorcum.

Paperny, D. M., Aono, J. Y., Lehman, R. M., Hammar, S. L., \& Risser, J. (1990). Computer-assisted detection and intervention in adolescent high-risk health behaviors. Journal of Pediatrics, 116, 456-462.

Rice, R. E. (2006). Influences, usage, and outcomes of Internet health information searching: Multivariate results from the Pew surveys. International Journal of Medical Informatics, 75, 8-28.

Scheier, M. F., \& Carver, C. S. (2003). Goals and confidence as self-regulatory elements underlying health and illness behavior. In L. Cameron \& H. Leventhal (Eds.), The self-regulation of health and illness behavior (pp. 17-41). New York: Routledge. 


\section{Author biographies}

RIK CRUTZEN, MSc, MA, is employed as researcher with a background in psychology and e-communication.

JASCHA DE NOOIJER, $\mathrm{PhD}$, is assistant professor specialised in nutrition and e-health.
MATH J. J. M. CANDEL, $\mathrm{PhD}$, is assistant professor and his research interests include multilevel analysis.

NANNE K. DE VRIES, PhD, is full professor and head of the Department of Health Education and Health Promotion. 